\title{
糖とタンパク質による油脂可溶化物の $\mathrm{O} / \mathrm{W}$ エマルジョンへの変換 ${ }^{\dagger}$
}

\author{
小野文 夫*・青山康 雄*
}

\section{Conversion into o/w Emulsion of Cottonseed Oil Solubilized with Protein and Carbohydrate}

Fumio Ono and Yasuo Aoyama

\begin{abstract}
Some changes of cottonseed oil solubilized in aqueous solution of saccharose and polypeptone were observed in dilution with water. Microscopic observation of the solubilizate did not show any dispersion image of oil droplets except saccharose crystals, even though it was stained with fuchsine or sudan III. However, dilution of the solubilizate with water gave the image of dense globular dispersion of oil and the solubilizate converted to cream or $\mathrm{o} / \mathrm{w}$ emulsion. Turbidity of the resulting emulsion increased and the amount of the free oil extractable by ether washing decreased as agitation time for solubilization increased. A part of polypeptone in the aqueous solution was apparently transferred into the cream layer after centrifugation by absorption on the surface of the oil droplets. Average size measured by Coulter counter method of the oil droplets dispersed in $0.85 \%$ sodium chloride solution was about 5 microns. In the dense creamy emulsion some parts of saccharose in the aqueous solution was supposed to exist in the state of partial micelle structure with the other components. These results indicate a possibility of the new procedure for preparing $o / w$ emulsion.
\end{abstract}

(Received Dec. 23, 1977)

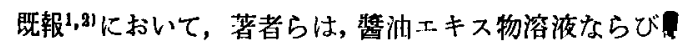
にそのモデル溶液としての, サッカロースとポリペプト ンの混合溶液が特定高濃度条件下で, 油脂を包容して非 哂濁性の安定分散系をなすことを述べた。そして，本現 象がミセル形成能を有する水溶性の糖類と, 界面活性を 有する水溶性タンパク質またはタンパク分解物とによる 混合ミセルの形成，ならびに，その生成ミセルへの油脂 の浸透溶解による, いわゆる可溶化現象にもとつくこと を推定した8,4!。

可溶化現象は界面活性埥溶液のミセル挙動として知ら

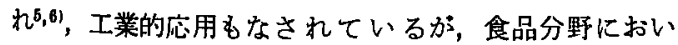
ては，界面活性戍の高濃度の使用が応用上の障害とな り，今日まで見るべき知見は得られていない。その意昧
で，食品の基本構成物である糖とタンパク質とによって なる本現象は，食品領域における可溶化現象の応用 ${ }^{7}$ こ とに，油脂や油性物質の新規な分散様式を可能にするむ のとして興味深く思われる。

本報に沶いては，サッカロースとポリペプトンを水相 の溶質モデルとして得た油脂可溶化物について, 加水展 開する際の油脂の分散挙動ならびに水相成分の消長を検 討し，展開液のエマルジョンとしての評価を行った。

\section{実 験 方 法}

\section{1. 油脂可溶化物の調製}

前報 2)に述べた方法と同様に，暞肉熱水抽出物の土夕 ノール沈殿区分（乾固物として TN：14.16\%）をボリ

$†$ 嶈油成分による油脂可溶化現象（第 8 報）

Solubilization Phenomenon of Fats and Oils by Solid Components of Soy Sauce (Part 8)

*キッューマン掣油株式会社中央研究所（千葉県野田市野田 399）

Central Research Laboratories Kikkoman Shoyu Co., Ltd. 399 Noda, Noda-shi, Chiba-ken 
ペブトンとして用い，サッカロースとともに溶解して所 定濃度の水相を調製した。ついで，これに所定量の綿実 油を徐々に加えながら予備混合したのち，Kenwood ミ キサーで䁌排し均質状とした。

\section{2. 加水展開液の濁度および遊離油量}

油脂可溶化物の $0.01 \%(\mathrm{w} / \mathrm{v})$ 希翻液について，線实 油の微滴分散にもとづく濁度をポイック積分球式濁度活 SEP-PT 501 型（日本精密光学製）を用いて測定した。 使用七ルは $10 \mathrm{~mm}$ とし，標準カオリン濁度液における PPM 換算濃度として表わした。

遊離油量の測定は伊藤らの方法 ${ }^{8)}$ に潐じて行い，等量 の蒸貿水で加水展開して得たクリーム状物 $10 \mathrm{~g}$ に対し， $20 \mathrm{~m} l$ のエチルエーテルを加え柽くかきまぜて遊離油を エーテルに移行させて分別した。これをさらに 3 回反復 し減圧下でェーテルを溜去した。

\section{3. クリーム層への移行糖, 㠉素量}

油脂可溶化物を 2 倍量の蒸留水で展開し，これを遠心 分離 $(8,000 \mathrm{rpm}, 10 \mathrm{~min})$ して浮上したクリーム層を 沪別した。本沪液の糖および窒素量を定量し，もとの含 量との差をクリーム層への移行量とし，その百分桼で示 した。なお，糖はベルトラン法をた音素（TN）はケール ダール法により測定した。

\section{4. 粒度分布および显微鏡観察}

分散油滴の粒度分布測定はコールターカウンター法・ により行い，試料濃度 $0.005 \%$ の加水展開希釈液它コ一 ルターカウンター MODEL ZB (Coulter Electronics, Inc. 製) により測定した。電解液には $0.85 \%$ 食塩水を 用い希釈液とした。アパーチャーチューブは 30 および 100 ミクロンを使用した。

綿実油の分散状態は顕微鏡観察を行い, 油脂可溶化物 においては水溶性色素フクシンおよび油 溶性色素ズダンIIIの粉末をそれぞれあら かじめ混在させ，色素の溶解および掋敞 状態を観察した。また，加水展開の際の 油滴の解離状態はスライドグラス上で水 と接触させる方法で観察した。

\section{実験結果および考察}

1. 顕微鏡観察による油脂の分散状態 油脂可溶化能を発現する糖とタンパク 質混合混液の濃度条件2)のうち，ここで はサッカロース $60 \%(\mathrm{w} / \mathrm{w})$ ，ポリペプ トン $2.82 \%(\mathrm{w} / \mathrm{w})(\mathrm{TN} と し て$ 水相当 り $1.0 \%, w / w)$ となる水相を用い, こ
れに攪抖下で 1.5 倍量 (w/w) の綿実油を加え, 含油量 $60 \%(\mathrm{w} / \mathrm{w})$ の油脂可溶化物を得た。こうして得た油脂 可溶化物の顕微蹱観察結果を Fig. 1 に示した。本図中， 1ー、はあらかじめズダンで而染色した綿实油を用いて得 た油脂可溶化物を示し，サッカロース結晶の点在を認め たほかは均質に近い連続相をなした。また，1-bおよび 1-cはそれぞれフクシンおよびズダン而の色素粉末を油 脂可溶化物に混在させ, 30 分静置後の色素の溶解, 拡散 状態を示す。このように，染色または非染色の油滴の分 散像は観察されず，色素は一㥞な拡散を示した。このこ とは，ミセル形成濃度下の水相自体難溶性色素の可溶化 能を有することす関係するが，值接には水相と油相が互 に溶解に近い状態で混在して，独立した油滴として存在 しないこと家するのと推定された。

Fig. 2 は油脂可溶化物を加水展開する際の観察図を示 し，スライドグラス上の油脂可溶化物 (2-a) に蒸留水 を滴下して接触させたときの油滴の解離する状態を 2-b に示した。また，2-cは 2 倍に加水展開したクリーム状 物の分散状態を示す。このように, 油脂可溶化物を加水 展開する場合には，裖密な微細油滴の分散像を与えるこ とが認められた。すなわち，糖と界面活性タンパクの形 成するミセルにとり込まれた可溶化状態の油脂は，水と の接触による糖の低濃度化とミセル構造の喪失ととも に，界面活性タンパを吸着したかたちで o/w エマル ジョンに変換するむのと考えられた。

\section{2. エマルジョン形成に及ぼす提拌度の影響}

粕とタンパク質の形成するミセルへの油脂の分散また は浸透の程度は，これを加水展開してェマルジョンとす る場合のエマルジョンの性状に影響する。同一組成の水 相に対して，2 倍量の線実油を子薉混合し，kenwood
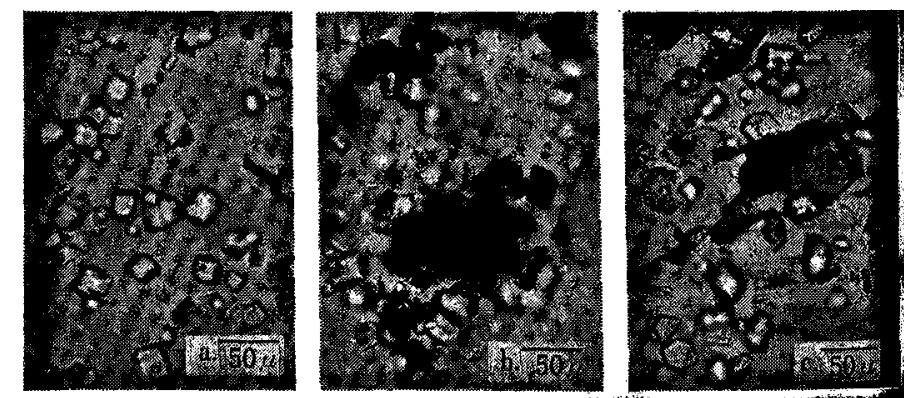

Fig. 1. Optical microscope views of the oil-solubilizate with some dyes, consisting of $60 \%$ cottonseed oil, $24 \%$ saccharose, $2.82 \%$ polypeptone and $13.18 \%$ water.

a: cottonseed oil was stained with sudan III prior to solubilization b: with fuchsine basic powder, after $30 \mathrm{~min}$. standing

c: with sudan III powder, after 30 min. standing 

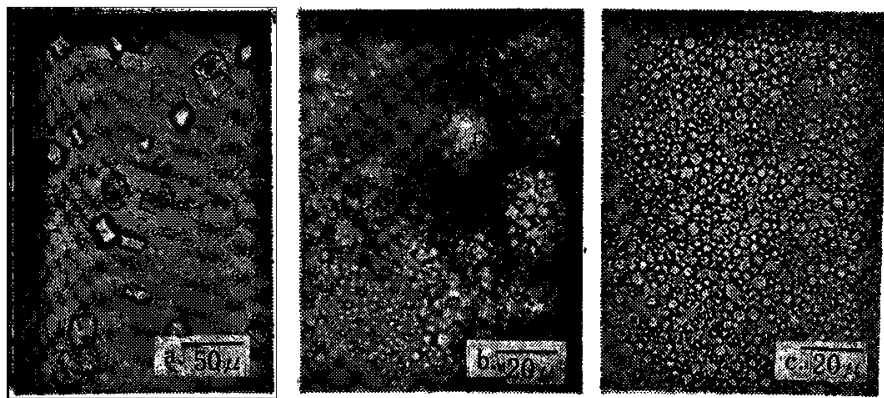

Fig. 2. Optical microscope views of the $o / w$ emulsion obtained by dilution of the solubilizate with water

a: before dilution (oil-solubilizate)

b: contacted with a drop of water

c: diluted with the equal amount of water

ミキサーで所定時間鲅捧して油脂可溶化物を得，攪拌時 間とそれらの加水展開液の濁度および遊離油量の関係を 検討し, Fig. 3 の結果を得た。予備混合して得た油脂可 溶化物は kenwood ミキサーによる攪汼時間とともに著 しく高粘稠化し，その展開希釈液の示寸綿实油の微滴分 散に基うく濁度は急激に増加し，攪找 20 分区で最大を示

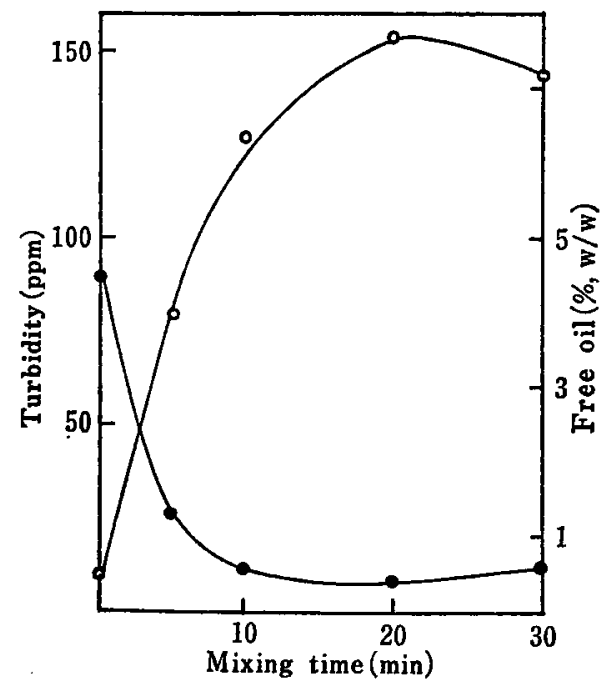

Fig. 3. Effects of mixing time of the oilsolubilizate on turbidity and the amount of free oil of the $o / w$ emulsion obtained by dilution of the solubilizate with water

Two parts of cottonseed oil were solubilized in one part of the aqueous solution of $60 \%$ saccharose and $1 \%$ polypeptone as TN, by preparatory handmixing.

$0-O$ turbidity of the $0.01 \%$ aqueous solution

- percent of free oil liberated by dilution with equal amount of water
した。攪找 30 分区では油脂可溶化物は ゲル状となり，㨨捧によって破断して， 切片表面に遊離油它生じ潈度は低下し た。一方, 遊離油量の推移は濁度の变化 と逆の関係にあり，鄮捧 20分区で $0.5 \%$ 前後にまで低下し，綿実油のほとんどが 保護コロイドの状態にあることが示され た。

\section{3. クリーム圓に移行する水相成分}

前項で得た種々の翼拌度の油脂可溶化 物を加水展開し，遼心分離によって浮上 するクリーム層への糖㧍よび空素の移行 率を求め，Fig. 4 を得た。水相成分のう ち糖については，その $20 \%$ 弱がクリーム層に移行し， 筧捧時間に対してほぼ一定であって，エマルジョンの進 行程度との関係は認められなかった。この糖は分散油滴 の間げきに保持されたものがほとんどで，一部はクリー ム中ミセル状態で存在するものと推定された。なお，水 洗を反復して得たクリーム層は糖の呈色反応101を示さな いことから，クリームの形成には糖が関与しないむのと 考えられた。

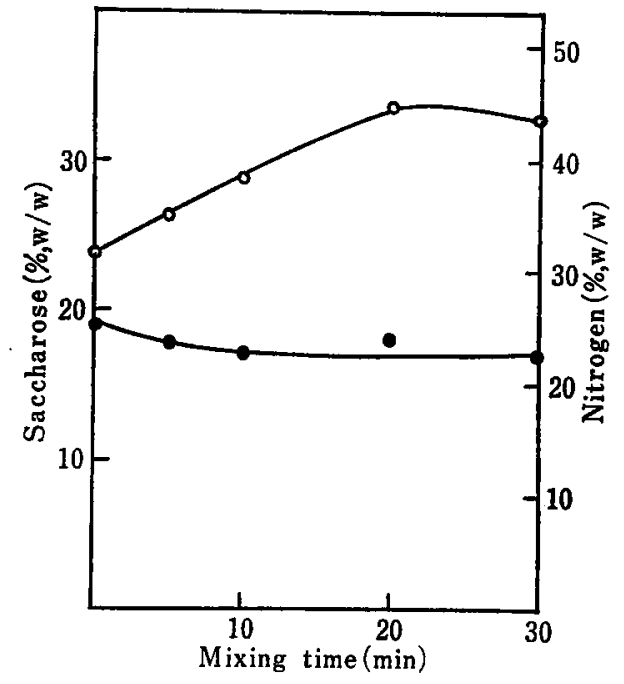

Fig. 4. Effects of mixing time of the oilsolubilizate on the amount of saccharose and nitrogen transferred into the creaming layer

One part of the oil-solubilizate was diluted with two parts of water and the creaming layer after centrifugation at $8000 \mathrm{rpm}, 10 \mathrm{~min}$. was separated by filtration.

- - saccharose, $\mathrm{O}-\mathrm{O}$ nitrogen 
一方，空素は先の濁度変化と同傾向で推移し，㨨掉度 の増加に伴って，クリーム層への移行量は増加した。こ のことは界面活性タンパクとしてのボリペプトンが油脂 可溶化物を加水展開する際のエマルジョン形成に密接に 関与することを示するのと思われた。

4. エマルジョン形成に及ぼすポリペプトン湌度の影 恼

種々のポリペプトン濃度となる水相を用いて油脂可溶 化物を調製し，それらを加水展開してェマルジョンとし ての性状を検討した。なお，水相の糖濃度は $60 \%(\mathrm{w} / \mathrm{w})$ とし, 添加綿実油量は水相の 1.5 倍量 $(\mathrm{w} / \mathrm{w})$ として行 った。

Fig. 5 は希釈夜の濁度ならびにクリーム層へ吸着移 行した窒素量の測定結果を示す。ボリペプトンが低洤度 の場合には，綿実油は充分な可溶化浸透を示さず，不均 質，不安定状態であって，これを加水展開し迼心分離す るときには分散油滴は会合，合一して分離油層をなし た。一方，TN 浱度として $0.8 \%(\mathrm{w} / \mathrm{w})$ 以上の水相を 用いるときには含油物は均質状態を示し，可溶化が達成

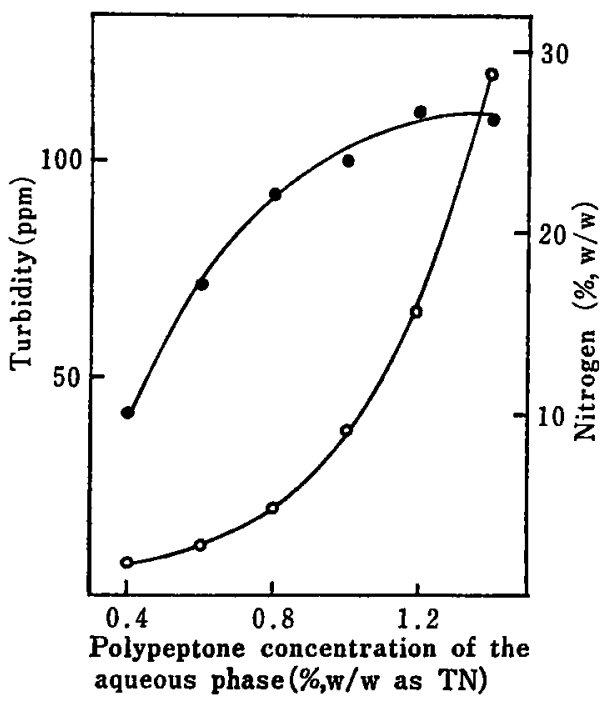

Fig. 5. Effects of polypeptone concentration of the aqueous phase in the oil-solubilizate on turbidity of the $\mathrm{o} / \mathrm{w}$ emulsion and the amount of nitrogen transferred into the creaming layer

1.5 parts of cottonseed oil were solubilized in 1 part of the aqueous solution of $60 \%$ saccharose and polypeptone of concentration indicated.

$\mathrm{O}-\mathrm{O}$ turbidity of $0.01 \%$ aqueous solution

- nitrogen transferred in the creaming layer
されるものとみなされ，それらのエマルジョン変換物は TN 濃度の增加とともに濁度の急激な上昇を示し，ま たクリーム層への窒素の移行量も增加し，安定なクリ 一ム層をなした。

このように, 油脂可溶化物の加水展開によるエマルジ ョン形成においては，水相成分中の界面活性タンパ々 してのポリペプトンの濃度が著しく影響することが認め られ，ポリぺプトンが分散油滴に吸着してエマルジョン の安定化に関与していることを示した。なお，窒素の吸 着移行率は図示したように，ほぼ 30\% まで増加し以後 一定となる傾向を示すことから，ポリペプトン中，分散 油滴に吸着できる窒素成分比率の存在が示唆された。

5. エマルジョン变換油滴の粒度分布

前項 2 で得た油脂可溶化物のうち，㩭捧時間 5 分区お よび 30 分区について，それらの希釈液における分散油滴 の粒度分布測定を行い, Fig. 6 の結果を得た。本困に示 したように，両試料とも分散油滴はほほ 2〜20 ミタロン 間に分布し，粒径 5 ミクロン付近に単一のピークを示し た。鄮挥時間との関係では，㩭挥 30 分区で明らかに低 粒度区の堌加が認められ，一方，高粒度区む僅かな増加 を示し，先の濁度変化および遊離油量の変化とも一致す ることが認められた。累積百分率 $50 \%$ 位における值か ら求めた平均粒径は筧挷 5 分区で 5.2 ミクロ，立た， 30 分区で 4.7 ミクロンとなり，油脂可溶化における摫拌 度がェマルジョンの分散油榈径に影䋨し，低粒度化岩も

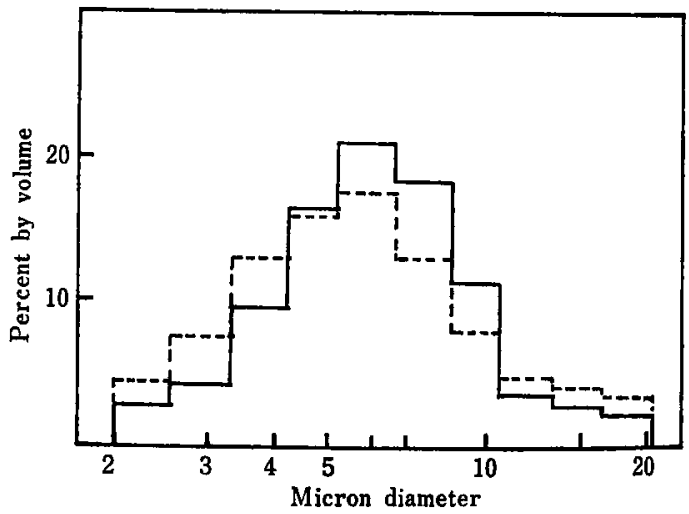

Fig. 6. Relation between mixing time of the oil-solubilizate and size distribution of oil droplets in the $0 / w$ emulsion obtained by dilution with water.

Composition of the oil-solubilizate was shown in

the sublegend of Fig. 3

- mixed for $5 \mathrm{~min}$.

..... mixed for $30 \mathrm{~min}$. 
たらすことが示された。

なお，低希釈度の場合のクリーム状物における粒度分 布は上記結果とは異ることが推定され，この場合には， 球状分散物は糖を保持して部分的にミセル棈造をなして いるものと考えられた。

以上に示したように，本油脂可溶化物は糖と界面活性 タンパとが特定高浱度溶液下で形成するミセルに油脂 が浸透し, 界面活性タンパクの有する疎水基によって吸 着安定化したものと推定され，また，これを加水展開す るときには，ミセルの親水性部分に水が浸透し，ミセル 構成物としての糖を溶解低濃度化し，ミセル構造の崩填 とともに，油脂はタンパクを吸着して解離し，o/wエ マルジョンに変換するむのと考えられた。

一方, こうして得られる油脂可溶化物は適宜のフレー バーリングにより油脂食品に応用》する場合には，油脂 の釈化分散性に基づいてミルクようの呈味により高い㖺 好性を示し，消化性にもすぐれることが示唆され，さら に, エマルジョンの調製方法としての面からも本現象が 興味あるむのと思われた。

\section{要 約}

サッカロースとポリペプトンを水相の溶質モデルとし てなる油脂可溶化物について, 加水展開する際の油脂の 分散挙動を検討した。顕微鏡観察において,フクシンお よびズダン且による染色は油脂可溶化物における油脂の 分散像を与えなかったが, 水との接触は油滴家解離させ,

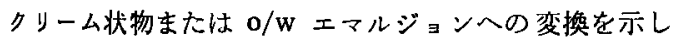
た。

油脂可溶化のための䚌拌は系の粘稠化ととるに，エマ ルジョンにおける油脂の微滴化を促進し, 遊離油量を減
少させた。また, 水相成分中のボリペプトンは分散油滴 への吸着によるクリーム層への移行を示し, エマルジョ ンの安定化に関与するすすと考えられた。

コールターカウンターによる希薄エマルジョンの分散 油滴の平均径は 5 ミロクン前後を示し, これらの結果は 新規なエマルジョンの調製方法としての可能性をる示唆 した。

終りに, 本研究を進めるに際し，終始御指導を賜わ りょしたキッコーマン俆油株式会社常務取締役横塚保博 士，同取締役中央研究所長井口信義博士ならびに同所那 須野精一博士に深謝いたします。また，御愳篤な御指導 と本稿の御校閲它晹わりました東京農業大学教授小原哲 二郎博士に梁く感謝いたします。また，实験に御協力い ただいた当所針替千恵子氏ならびに発表を詐可された本 社役員各位に厚く御礼申上げます。

\section{文献}

1）小野交夫・青山康雄：食品工誌，23，306(1976).

2）小野交夫・青山康雄：食品工誌，24，459(1977).

3）小野文夫・青山康雄：食品工誌，24，230(1977).

4）小野交夫 - 青山康雄：食品工誌, 25, 275(1978).

5) Fendler, J.H. and Fendler, E.J.: catalysis in Micellar and Macromolecular Systems, (Academic Press), p. 42 (1975).

6) 伊勞村寿三：工業化学誌, 58, 815 (1955).

7) ONo, F. and AoYama, Y.: US patent, 4, 049, 831 Sept. 20, (1977).

8）伊蔯敞敏 -中西武雄：農化，48，(4),239(1974).

9) Wachitel, R.E. and Lamer, V.K.: J. Colloid Sci., 17, 531 (1962).

10)百瀬 勉：有機定性分析（広川書店)，p. 144 (1954).

(昭和 52 年 12 月 23 日受理) 